\title{
Kelayakan Pengembangan Bahan Ajar Digital Berkearifan Lokal Sebagai Bahan Literasi Bahasa Berbasis Kelas Serta Pengaruhnya Terhadap Karakter Sosial Dan Keterampilan Berbahasa Siswa Sekolah Dasar
}

\author{
Syaiful Musaddat ${ }^{1}$, Ni Ketut Suarni ${ }^{2}$, Nyomen Dantes ${ }^{3}$, Ida Bagus Putrayasa ${ }^{4}$, I Gede Rasben Dantes ${ }^{5}$ \\ ${ }^{123345}$ Program Pascasarjana Universitas Pendidikan Ganesha \\ Email: syaiful_musaddat@unram.ac.id ${ }^{1}$, niketut.suarni@undiksha.ac.id ${ }^{2}$, dantes@undikshac.id ${ }^{3}$, \\ ib.putrayasa@undiksha.ac.id ${ }^{4}$ rasbendantes@undiksha.ac.id ${ }^{5}$
}

\begin{abstract}
Abstrak. Tulisan ini membahas kelayakan pengembangan bahan ajar digital berkearifan lokal sebagai bahan literasi berbasis kelas serta pengaruhnya terhadap karakter sosial dan keterampilan berbahasa siswa Sekolah Dasar. Kelayakan ini akan ditinjau dari dua hal, yaitu (1) hal-hal yang mendasari perlunya dilakukan penelitian; dan (2) hasil kajian teori yang mendukung penelitian. Di samping itu, juga disajikan alternatif rancangan penelitian dimaksud. Penelitian ini merupakan penelitian kepustakaan atau studi literatur, yakni menggunakan metode metaanalisis. Data dikumpulkan melalui penelusuran jurnal elektronik melalui Google Scholar dengan kata kunci "bahan ajar digital", "kearifan lokal", dan "literasi bahasa". Data dianalisis dengan menggunakan analisis deskriptif kualitatif dan disajikan dengan metode nonformal. Berdasarkan hasil dan pembahasan dapat disimpulkan bahwa kajian berupa penelitain dan pengembangan bahan ajar digital berbasis kearifan lokal serta pengaruhnya terhadap karakter sosial dan keterampilan berbahasa produktif siswa kelas V SD perlu dilakukan karena dua pertimbangan utama. Kedua pertimbangan dimaksud adalah (1) terdapat sejumlah fakta yang mendasari bahwa kajian ini layak dijadikan sebagai masalah penelitian, antara lain: (a) keharusan peserta didik untuk memeiliki kompetensi global berupa empati dan kemampuan berkomunikasi; (b) sistem pendidikan Indonesia masih belum berhasil melahirkan generasi berkarakter, cerdas, dan terampil; (c) keharusan untuk menggunakan teknologi dalam pendidikan; (d) belum efektifnya program literasi berbasis kelas di SD; dan (e) banyaknya hasil penelitian pengembangan berbasis teknologi yang telah berhasil meningkatkan kualitas pembelajaran; dan (2) terdapat sejumlah hasil kajian teori yang juga memperkuat jika penelitian ini dilaksanakan, yakni teori tentang: (a) bahan ajar digital; (b) kearifan lokal; (c) literasi bahasa berbasis kelas; (d) karakter sosial; dan (e) keterampilan berbahasa. Di samping itu, juga diusulkan model penelitian dan pengembangan yang dapat digunakan, yaitu model R\&D versi Borg dan Gall, yang terdiri atas 10 langkah pengembangan.
\end{abstract}

Kata Kunci: Bahan Ajar, Digital, Kearifan Lokal, Literasi Bahasa, Karakter Sosial, dan Keterampilan Berbahasa

Abstract. This paper discusses the feasibility of developing local wisdom digital teaching materials as classroom-based literacy materials and their effect on the social character and language skills of elementary school students. This feasibility will be reviewed from two things, namely (1) the things that underlie the need for research; and (2) the results of theoretical studies that support the research. In addition, an alternative research design is also presented. This research is a literature study or literature study, which uses the meta-analysis method. Data was collected through electronic journal searches through Google Scholar with the keywords "digital teaching materials", "local wisdom", and "language literacy". Data were analyzed using qualitative descriptive analysis and presented with non-formal methods. Based on the results and discussion, it can be concluded that a study in the form of research and development of digital teaching materials based on local wisdom and its influence on the social character and productive language skills of fifth grade elementary school students needs to be done because of two main considerations. The two considerations are (1) there are a number of facts that underlie that this study deserves to be used as a research problem, including: (a) the need for students to have global competencies in the form of empathy and communication skills; $(b)$ the Indonesian education system has not yet succeeded in producing a generation of character, intelligence, and skill; $(c)$ the necessity to use technology in education; $(d)$ the ineffectiveness of classroom-based literacy programs in elementary schools; and $(e)$ the many results of technology-based development research that have succeeded in improving the quality of learning; and (2) there are a number of theoretical study results that also strengthen if this research is carried out, namely theories about: (a) digital teaching materials; (b) local wisdom; (c) classroom-based language literacy; (d) social character; and (e) language skills. In addition, a research and development 
model that can be used is also proposed, namely the Borg and Gall version of the R\&D model, which consists of 10 development steps.

Keywords: Teaching Materials, Digital, Local Wisdom, Language Literacy, Social Character, and Language Skills

\section{PENDAHULUAN}

Mahasiswa, guru, dan dosen harus mampu menulis karya ilmiah. Mahasiswa harus mampu menyusun skripsi, tesis, atau disertasi untuk bisa menyelesaikan program S1, S2, atau S3. Guru dan dosen yang akan naik pangkat juga harus mampu menghasilkan karya ilmiah. Karya ilmiah merupakan jenis tulisan yang memiliki karakteristik dan gaya tersendiri. Karya ilmiah disusun dengan aturan-aturan yang sangat ketat. Karya ilmiah merupakan hasil pemikiran ilmiah tentang disiplin ilmu tertentu yang disusun secara sistematis, benar, logis, utuh, bertanggung jawab, serta menggunakan bahasa yang benar (Wardani, 2017 dan Nur, dkk., 2018).

Khusus untuk tulisan ilmiah berupa penelitian untuk tesis dan disertasi, harus dilandasi argumentasi yang kuat. Argumentasi yang diajukan harus memiliki dasar yang memadai. Untuk memperoleh dasar yang memadai dimaksud, tesis dan disertasi biasanya diawali dengan penelitian pendahuluan (penelitian dasar). Penelitian dasar dapat berupa survei atau kajian literatur menggunakan metode metaanalisis. Kajian literatur manjadi sangat urgen untuk menujukkan layak-tidaknya penelitian tesis atau disertasi.

Oleh karena itu, melalui tulisan ini akan disajikan hasil penelitian literatur menggunakan metaanalisis dalam menetapkan layak-tidaknya dilakukan penelitian dan pengembangan bahan ajar digital berkearifan lokal. Kearifan lokal merupakan nilai-nilai, sifat-sifat penting atau nilai kebijaksanaan dan nilai pendidikan pada berbagai dokumen dan prilaku masyarakat, yang turut membentuk watak dan kepribadian masyarakat ke arah yang lebih baik. Kearifan lokal sebagai kebijakan setempat atau pengetahuan setempat dapat dimaknai sebagai pandangan hidup, ilmu pengetahuan, dan berbagai strategi kehidupan masyarakat lokal dalam menjalani kehidupan dengan berbagai permasalahannya (Koentjaraningrat, 2009; Rahyono 2009). Nilai-nilai ini digunakan sebagai panduan atau pedoman untuk membangun pola hubungan dan memperjuangkan tujuan hidup, yang menjadi sumber nilai bagi masyarakat pendukungnya (Wahab, 2012). Nilai-nilai kearifan lokal perlu dilestarikan dan direvitalisasi agar tidak lapuk termakan zaman. Salah satunya melalui pengembangan bahan ajar berkearifan lokal. Bahan ajar sangat penting dalam program pembelajaran atau pelatihan. Menurut Weidenmann (dalam Tim PLPG Unram, 2018), terdapat berbagai jenis bahan ajar. Salah satunya adalah bahan ajar multimedia interaktif (interactive teaching material) seperti CAI, CD multimedia interaktif, dan bahan ajar berbasis web. Bahan ajar harus dikembangkan dengan memperhatikan berbagai persyaratan agar efektif dan efisien. Bahan ajar harus relevan dengan kurikulum, perkembangan dan lingkungan siswa, berisi konsep dan prinsip, ada keseimbangan antara teori dengan praktik, dan mendorong daya imajinasi peserta didik (Wadi, 2013; Karhami dalam Komalasari, 2010).

Demikian pula dengan bahan ajar untuk program literasi. Bahan ajar untuk literasi perlu dikembangkan agar dapat mempercepat proses pembudayaan literasi. Hal ini karena pembudayaan literasi yang berkesinambungan akan dapat menjadikan literasi sebagai program yang akan menghasilkan generasi berkarakter. Kurikulum 2013 telah menekankan bahwa implementasi strategi literasi akan meningkatkan kecakapan berpikir tingkat tinggi peserta didik SD dan menjadikannya berkarakter (Depdikbud, 2018). Literasi akan menjadikan siswa memiliki karakter sosial dan keterampilan berkomunikasi yang memadai (Marhaeni, dkk., 2018). Karakter sosial merupakan kecerdasan yang berkaitan dengan kemampuan seseorang untuk 
berinteraksi dengan orang lain, yang ditandai dengan kemampuan memperkirakan perasaan, temperamen, suasana hati, maksud dan keinginan dari pasangan interaksinya (Kurniati, 2016). Sementara itu, keterampilan berkomukasi merupakan keterampilan menjalin hubungan dengan orang lain. Keterampilan ini sangat penting sebagai konsekuensi logis dari kodrat manusia sebagai mahluk sosial. Dalam konteks demikian, pengembangan bahan ajar harus terus dilakukan.

Penelitian dan Pengembangan (R\&D) adalah istilah yang biasa digunakan untuk menggambarkan kegiatan yang dilakukan oleh perusahaan dan entitas lain seperti pengusaha perorangan untuk menciptakan peningkatan produk dan proses. Dalam konteks pendidikan, penelitian pengembangan adalah suatu proses yang digunakan untuk mengembangkan dan memvalidasi produkproduk yang digunakan dalam pendidikan dan pembelajaran (Sugiyono, 2011 dan Arikunto, 2013). Richey dan Klein (2014) mengatakan, terdapat dua kategori penelitian pengembangan, salah satunya adalah studi pengembangan yang berfokus pada produk, program, proses, atau alat yang diberikan. Biasanya studi pengembangan ini tidak hanya membahas desain dan pengembangan produk, tetapi juga evaluasi. Dengan demikian, penelitian dan pengembangan yaitu penelitian yang menghasilkan produk, yang nantinya dapat diuji keefektifannya.

Terdapat beberapa model $R \& D$ yang berkembang, yakni R\&D: versi Borg dan Gall, model ADDIE, model Dick and Carey, dan model 4D. Pertama. R\&D versi Borg dan Gall (1996) merupakan model penelitian pengembangan yang dengan serangkaian langkah yang dilakukan secara siklus. Pada setiap langkah yang dikembangkan selalu mengacu pada hasil langkah sebelumnya dan pada akhirnya diperoleh suatu produk pendidikan yang baru. Tahap penelitian dan pengembangan versi Borg \& Gall terdiri atas 10 langkah, yaitu: (1) penelitian/studi pendahuluan dan pengumpulan data (research and information collecting), (2) perencanaan (planning), (3) pengembangan draf produk (develop preliminary form of product), (4) uji coba lapangan awal (preliminary field testing) atau dalam penelitian ini merupakan uji validasi oleh ahli, (5) merevisi hasil uji coba lapangan awal (main product revision), (6) uji coba lapangan utama atau dalam penelitian ini adalah uji coba skala kecil (main field testing), (7) merevisi produk hasil uji lapangan utama (operational product revision), (8) uji pelaksanaan lapangan atau dalam penelitian ini adalah uji coba lapangan/kelas (operational field testing), (9) revisi produk akhir (final product revision), dan (10) diseminasi dan implementasi (dissemination and implementation). Kedua. Model ADDIE (Analysis, Design, Development, Implementatian, Evaluation). Tahapan penelitian model ADDIE terdiri atas 5 langkah, yakni yaitu; (1) tahap Analysis, menganalisis muatan atau isi model yang akan dikembangkan; (2) tahap Design, membuat draf dari model yang akan dikembangkan; (3) tahap pengembangan (development) merupakan tahap proses membuat model; (4) tahap implementation adalah tahap mengaplikasikan atau ujicoba model yang telah dikembangkan; dan (5) tahap Evaluation adalah untuk menguji keefektifan dari model yang telah dikembangkan tersebut (Richey dan Klein, 2014). Ketiga. Model Dick and Carey.(1996). Model Dick \& Carey yaitu sebuah model yang dikembangkan oleh Walter Dick \& Lou Carey (2005). Borg \& Gall, (2003) dalam bukunya "Educational Research" mengatakan bahwa model Dick \& Carey adalah suatu model pengembangan instruksional yang sangat sistematis. Mulai dari tahap awal pengembangan sampai desiminasi produk dengan melakukan proses perbaikan yang berlangsung secara terus menerus sampai standar kualitas produk yang dikembangkan tercapai, yaitu (efektif, efisien, dan berkualitas). Ini adalah tahapan pengembangan instruksional yang tidak dimiliki oleh model pengembangan instruksional lainnya. Urutan langkah-langkah model ini adalah: identifikasi tujuan atau analisis kebutuhan, analisis instruksional/analisis kecerdasan peserta didik, analisis karakteristik siswa, merumuskan tujuan kinerja, pengembangan 
instrumen, pengembangan strategi pembelajaran, pengembangan dan pemilihan bahan pengajaran, evaluasi formatif, merancang perangkat pembelajaran, revisi pengajaran. Keempat. Four-D Model (4D). Four-D Model disarankan oleh Sivasailam Thiagarajan, Dorothy S. Semmel, dan Melvyn I. Semmel (1974). Model ini terdiri dari 4 tahap pengembangan yaitu Define, Design, Develop, dan Disseminate atau diadaptasikan menjadi model 4-D, yaitu pendefinisian, perancangan, pengembangan, dan penyebaran.

Masalah utama yang akan dibahas melalui tulisan ini adalah kelayakan pengembangan bahan ajar digital berkearifan lokal sebagai bahan literasi berbasis kelas serta pengaruhnya terhadap karakter sosial dan keterampilan berbahasa siswa Sekolah Dasar. Kelayakan ini akan ditinjau dari dua hal, yaitu (1) hal-hal yang mendasari perlunya dilakukan penelitian dan pengembangan bahan ajar digital berkearifan lokal; dan (2) hasil kajian teori yang mendukung penelitian dan pengembangan bahan ajar digital berkearifan lokal. Di samping itu, juga disajikan alternatif rancangan penelitian dan pengembangan dimaksud.

\section{METODE PENELITIAN}

Penelitian ini merupakan penelitian kepustakaan atau studi literatur (literature review). Penelitian ini menggunakan metode metaanalisis, dengan tahapan merumuskan masalah lalu menelusuri hasil penelitian yang relevan untuk dianalisis. Dalam hal ini digunakan penelusuran jurnal elektronik melalui Google Scholar dengan kata kunci "bahan ajar digital", "kearifan lokal", dan "literasi bahasa". Data dianalisis menggunakan metode analisis deskriptif kualitatif dan disajikan dengan metode nonformal, yakni penyajian dengan kata-kata atau kalimat dan bukan dengan simbol-simbol (Mahsun, 2017)

\section{HASIL DAN PEMBAHASAN}

Hasil penelitian ini disajikan dalam tiga subbahasan, yaitu (1) fakta pendukung yang mendasari perlunya dilakukan penelitian pengembangan bahan ajar digital berkearifan lokal sebagai bahan literasi berbasis kelas serta pengaruhnya terhadap karakter sosial dan keterampilan berbahasa siswa Sekolah Dasar; (2) hasil kajian teori yang mendukung perlunya pengembangan bahan ajar digital berkearifan lokal sebagai bahan literasi berbasis kelas serta pengaruhnya terhadap karakter sosial dan keterampilan berbahasa siswa Sekolah Dasar; dan alternatif rancangan penelitian pengembangan dimaksud.

\section{Fakta Pendukung}

Fakta pendukung yang dimaksud dalam kajian ini adalah fakta-fakta yang mendukung perlunya dilakukan pengembangan bahan ajar digital berkearifan lokal. Fakta-fakta dimaksud dapat berupa hasil penelitian dan atau hasil pemikiran yang relevan. Melalui kajian literatur, ditemukan sejumlah fakta yang mendukung perlunya pengembangan bahan ajar digital berkearifan lokal sebagai bahan literasi berbasis kelas serta pengaruhnya terhadap karakter sosial dan keterampilan berbahasa siswa Sekolah Dasar. Fakta-fakta dimakud adalah sebagai berikut.

Pertama, siswa harus memiliki kompetensi global untuk dapat memenangkan persaingan di era Industri 4.0 dan era society 5.0. Hal ini karena teknologi telah menjadikan dunia tanpa batas. Semua sisi kehidupan manusia tidak bisa lepas dari teknologi, termasuk dunia pendidikan. Dalam konteks inilah siswa harus memiliki kompetensi global. Kompetensi global memiliki tiga dimensi yang saling bergantung, yaitu empati terhadap orang-orang dengan identitas budaya yang berbeda, kemampuan berkomunikasi, dan pengetahuan luas dan mendalam tentang ilmu pengetahuan (Reimers, 2019). Empati, kemampuan berkomunikasi, dan pengetahuan luas sangat urgen bagi setiap manusia karena keberadaanya sebagai mahluk sosial. Dalam kerangka ini, manusia akan selalu berinteraksi dengan menggunakan bahasa. Interaksi dan segala macam kegiatan dalam masyarakat akan lumpuh tanpa bahasa (Keraf, 2018). Maknanya adalah 
bahwa siswa juga harus memiliki kemampuan berkomunikasi yang baik.

Kedua, kegagalan Indonesia dalam peserta didik yang cerdas, terampil dan berkarakter. Muara kompetensi global adalah peserta didik yang cerdas, terampil dan berkarakter. Namun demikian, sistem pendidikan Indonesia sampai saat ini masih belum berhasil mencetak peserta didik yang demikian. Beberapa hasil kajian telah menunjukkan kegagalan itu. Indonesia berada pada urutan 5 di ASEAN dan posisi 108 di dunia di bawah Palestina, Somalia, dan Mongolia (https://news.okezone.com). Hasil penelitian Jaringan Pemantau Pendidikan Indonesia (JPPI) tentang Right to Education Index (RTEI), Indonesia berada di urutan 7 dari 14 negara sampel (Inggris, Kanada, Australia, Filipina, Ethiopia, Korea Selatan, Indonesia, Nigeria, Honduras, Palestina, Tanzania, Zimbabwe, Kongo dan Chili). Bahakan, Indonesia berada di bawah Ethiopia dan Filipina (Sahroji dalam https://news.detik.com/). Hasil studi TIMSS (Trends in International Mathematics and Science Study), juga menunjukkan bahwa siswa Indonesia berada pada ranking 36 dari 49 negara dalam hal melakukan prosedur ilmiah (Result Prom PISA, 2015).

Ketiga, orientasi pendidikan Indonesia masih pada isi/pengetahuan, bukan pada karakter peserta didik. Meskipun penanaman dan pengembangan karakter menjadi ciri pembeda pada penerapan K-13, namun karakter belum menjadi target utama. Sampai dengan awal tahun 2015, pendidikan formal Indonesia masih cenderung mengutamakan penguasaan sains dan teknologi saja demi memenuhi kebutuhan material dengan mengabaikan transformasi nilai-nilai kemanusiaan kepada generasi muda, baik pada pendidikan formal, informal maupun nonformal (Dantes, 2014). Menurut Am (2014), perkembangan IPTEK di abad XXI ini, dalam konteks kehidupan sosial, di satu sisi dapat mengangkat martabat manusia karena berbagai kemudahan yang diberikan teknologi sehinagga manusia lebih banyak berkarya, tetapi di sisi lain teknologi telah melindas hakikat kemanusiaan manusia itu sendiri. Dengan demikian, sangat diperlukan pengembangan karakter siswa (misalnya keterampilan sosial/interpersonal skill) dalam semua pembelajaran termasuk pembelajaran bahasa Indonesia, Sains, IPS, atau melalui berbagai program termasuk program literasi.

Keempat, literasi dapat mewujudkan peserta didik yang berkarakter. Literasi telah meluas pada berbagai bentuk dan dimensi, yaitu: literasi bahasa, numerasi, sains, digital, finansial, serta budaya dan kewarganegaaran. Kegiatan literasi dapat mewujudkan peserta didik yang berkarakter, lebih-lebih dengan memaksimalkan buku cerita yang relevan dengan kurikulum yang berlaku. Penggunaan buku cerita yang berhubungan dengan isi kurikulum dapat meningkatkan karakter siswa (kejujuran, kesabaran, dan kepatuhan untuk berdoa) bersamaan dengan kemampuan dalam mendengarkan dan membaca (Marhaeni, dkk., 2018: 517). Lebih lanjut dijelaskan bahwa cerita dapat digunakan sebagai alat pendidikan karakter.

Kelima, kemampuan literasi peserta didik Indonesia masih sangat rendah. Pada tahun 2017, Central Connecticut State University di Amerika Serikat melakukan penelitian tentang "Most Literate Nations in the World" dan menempatkan Indonesia pada posisi 60 dari 61 negara dari segi kemampuan membaca dan menulis. Indonesia hanya lebih baik dari Botswana, negara di Afrika. Terkait kemampuan membaca dan menulis ini, hasil penelitian Ismail pada tahun 2000 telah menyebutkan Indonesia rabun membaca dan lumpuh menulis (Ismail, 2003).

Keenam, kemajuan teknologi merupakan keharusan yang tidak dapat ditolak untuk perkembangan pendidikan. Kemajuan dan perkembangan teknologi 
tanpa batas semakin kencang berhembus, semakin menggejala, dan tak terbendung pada semua aspek kehidupan manusia. Semua sisi kehidupan manusia sangat tergantung pada teknologi. Dunia pendidikan juga tidak lepas dari ketergantungan pada teknologi. Oleh karena itu, salah satu pilar pendidikan dunia di abad 21 adalah keterampilan memanfaatkan teknologi, yaitu information media and technology skill. Brown (2018) menemukan bahwa praktek terbaik pada sekolah-sekolah model yang telah menerapkan program kemitraan untuk pendidikan abad 21 adalah (1) pengalaman belajar di sekolah sengaja dirancang terpadu di seluruh sekolah dengan memanfaatkan teknologi; dan (2) pengalaman belajar terhubung ke dunia luar dengan memanfaatkan teknologi. Dapat diasumsikan bahwa program literasi juga akan menjadi semakin efektif jika memanfaatkan teknologi. Dalam konteks ini, dibutuhkan teknologi untuk meningkatkan kualitas pendidikan, termasuk program literasi.

Ketujuh, terdapat banyak penelitian pengembangan berbasis teknologi yang telah berhasil meningkatkan kualitas pembelajaran. Penelitian-penelitian dimaksud, antara lain: (a) Mabruri, H., dkk. (2019) tentang pembelajaran dengan mobile sains; (b) Wijayanti, W dan Stefanus C.R (2019) tentang pembelajaran berbasis Teknologi sederhana berupa Power Point; (c) Chan, F., dkk. (2019) tentang multimedia interaktif dan instrument penilaian berbasis keterampilan proses dasar; (d) Madona, A.S. (2017) tentang modul pembelajaran IPS berbasis multimedia interaktif; (e) Setiawan, dkk. (2018) terkait multimedia interaktif buku digital 3D untuk kelas IV Sekolah Dasar; (f) Fadhilah, N. dan Dhea Adela (2018) tentang pembelajaran menggunakan multimedia berupa video, audio, gambar, dan teks yang ditampilkan menggunakan teknologi LCD proyektor dan handphone; dan Nurhayati (2016) tentang pengembangan multimedia interaktif muatan IPS berbasis inquiri pada siswa kelas $\mathrm{V}$.

Kedelapan, pelaksanaan program lierasi belum maksimal. Meskipun Gerakan Literasi Sekolah (GLS) telah dilaksanakan sejak 2016, tetapi program Literasi Bahasa Berbasis Kelas (LBBK) belum berjalan secara efektif. Menurut Temuan Musaddat dan Marhaeni (2020), terdapat beberapa indikator yang menunjukkan masih belum efektifnya pelaksanaan LBBK, yaitu sebagai berikut. Pertama, belum tersedia jadwal kegiatan atau program literasi kelas. Hampir semua sekolah yang diobservasi, tidak bisa menunjukkan jadwal kegiatan atau program literasi kelas; Kedua, kegiatan 15 menit membaca di kelas masing-masing masih sangat jarang dilakukan (hanya dilakukan ketika materi pelajaran bahasa Indonesia); Ketiga, kegiatan litersi kelas belum tercermin pada prangkat pembelajaran yang dikembangkan guru. Pada semua perangkat pembelajaran (RPP) guru dari sekolah-sekolah yang dikunjungi belum ada satupun yang pada RPP-nya terdapat program litersi; Keempat, kegiatan litersi kelas belum tercermin pada kegiatan pembelajaran yang dilaksanakan guru. Pada semua tahapan pembelajaran yang dilaksanakan tidak ada yang mencerminkan kegiatan literasi; dan Kelima, hubungan sekolah dengan keluarga dan masyarakat belum terjalin dengan baik. Termasuk dalam melaksanakan program literasi kelas. Hampir semua sekolah tersebut, belum melibatkan orang tua siswa (keluarga) dan masyarakat dalam melaksanakan kegiatan literasi kelas. Misalnya, sebagai model dalam pembelajaran/kegiatan literasi kelas. Menurut Elmacioğlu (2000), keberhasilan anak-anak di sekolah sangat terkait dengan lingkungan keluarga. Pollard dan Triggs (2000) juga menyatakan bahwa rumah, keturunan, evaluasi diri, dan usaha adalah di antara faktor-faktor yang mempengaruhi keberhasilan siswa (dalam Doğan dan Gönül Onur Sezer, 2010). 


\section{Teori Pendukung}

Bagian berikut mengulas sejumlah hasil kajian tentang beberapa teori pendukung dari masalah penelitian dan pengembangan ini. Hasil-hasil kajian dimaksud terkait dengan bahan ajar digital, kearifan lokal, literasi bahasa berbasis kelas, karakter sosial, dan keterampilan berbahasa.

\section{a. Bahan Ajar Digital}

Bahan ajar adalah segala bentuk bahan yang digunakan untuk membantu guru/instruktor dalam melaksanakan kegiatan pembelajaran di kelas. Bahan yang dimaksud bisa berupa bahan tertulis maupun bahan tidak tertulis. Bahan ajar merupakan seperangkat materi/substansi pembelajaran (teaching material) yang disusun secara sistematis, menampilkan sosok utuh dari kompetensi yang akan dikuasai siswa dalam kegiatan pembelajaran (Tim PLPG Unram, 2018). Lebih lanjut disebutkan bahwa bahan ajar berfungsi sebagai: (a) pedoman bagi guru yang akan mengarahkan semua aktivitasnya dalam proses pembelajaran, sekaligus merupakan substansi kompetensi yang seharusnya diajarkan kepada siswa, (b) pedoman bagi siswa yang akan mengarahkan semua aktivitasnya dalam proses pembelajaran, sekaligus merupakan substansi kompetensi yang seharusnya dipelajari/dikuasainya, dan (c) alat evaluasi pencapaian/penguasaan hasil pembelajaran. Dengan demikian, bahan ajar adalah seperangkat materi yang disusun secara sistematis sehingga tercipta lingkungan atau suasana yang memungkinkan siswa untuk belajar.

Berdasarkan teknologi yang digunakan, bahan ajar dapat dikelompokkan menjadi empat kategori, yaitu (1) Bahan cetak (printed) seperti handout, buku, modul, lembar kerja siswa, brosur, leaflet, wallchart, foto/gambar, model/maket; (2) Bahan ajar dengar (audio) seperti kaset, radio, piringan hitam, dan compact disk audio; (3) Bahan ajar pandang dengar (audio visual) seperti video compact disk, film; dan (4) Bahan ajar multimedia interaktif (interactive teaching material) seperti CAI (Computer Assisted Instruction), compact disk (CD) multimedia pembelajarn interaktif, dan bahan ajar berbasis web (web based learning materials). Sementara itu, Weidenmann (dalam Tim PLPG Unram, 2018) mengelompokkan bahan ajar menjadi tiga besar, yaitu: (1) audio, yang menyangkut radio, kaset, piringan hitam; (2) visual, yang menyangkut Flipchart, gambar, film bisu, video bisu, program komputer, bahan tertulis dengan dan tanpa gambar; dan (3) audio visual, yang menyangkut berbicara dengan gambar, pertunjukan suara dan gambar, dan film/video. Dalam konteks ini, bahan ajar dimaksud adalah bahan ajar multimedia. Adapun tipe bahan ajar multimedia yang dapat diusulkan untuk dipilih pada kajian ini adalah bahan ajar berbasis web.

$$
\text { Dalam pengembangan bahan }
$$
ajar, guru harus mampu memperhatikan hal-hal berikut: 1) potensi peserta didik berupa potensi intelektual, emosional, spiritual, sosial dan potensi vokasional; 2) relevansi dan karakteristik daerah, yaitu sesuai dengan daerah tempat tinggal peserta didik; 3) tingkat perkembangan fisik, yaitu terkait dengan intelektual, emosional, sosial dan spiritual peserta didik; 4) kebermanfaatan bagi peserta didik, yaitu memberikan yang dapat dirasakan peserta didik dalam waktu yang relatif singkat setelah suatu materi pembelajaran tuntas dilaksanakan; 5) relevansi, yaitu sesuai kebutuhan peserta didik dan tuntunan lingkungan; 6) alokasi waktu, yaitu sesuaikan dengan waktu yang sudah ditentukan (Wadi, 2013: 18). Karhami (dalam Komalasari, 
2010: 28) menjelaskan beberapa kriteria materi ajar yang esensial dalam kurikulum sekolah, yaitu: 1) materi yang mengungkapkan gagasan kunci dari ilmu; 2) materi sebagai struktur pokok mata pelajaran; 3) materi menggunakan metode inquiry pada setiap mata pelajaran; 4) berisi konsep dan prinsip; 5) ada keseimbangan antara teori dengan praktik; 6) mendorong daya imajinasi peserta didik. Pengembangan materi ajar dapat dilakukan melalui berbagai cara yang sesuai dengan keadaan, ketersediaan sumber, dan keahlian yang dimiliki oleh seorang guru. Terdapat tiga cara atau teknik yang dapat digunakan untuk mengembangkan materi ajar, yaitu adopsi, adaptasi, dan menulis sendiri. Demikian pula dengan bahan ajar atau materi ajar digital.

\section{b. Kearifan Lokal}

Kearifan lokal pada konteks ini, identik dengan nilai-nilai. Nilai sebagai suatu yang abstrak mengandung makna "keberhargaan" atau suatu ciri (sifat) yang dimiliki oleh suatu hal (Ghani dalam Mahyudi, 2008). Nilai juga dapat diartikan sebagai sifat (hal-hal) yang penting atau berguna bagi kemanusiaan. Dalam pengertian yang luas, nilai sangat menentukan baik dan buruknya sesuatu. Kearifan lokal dipandang sebagai nilai-nilai kebijaksanaan atau nilai-nilai pendidikan (tersurat maupun tersirat) pada berbagai dokumen dan prilaku kebiasaan masyarakat, yang turut membentuk watak dan kepribadian masyarakat ke arah yang lebih baik.

Kearifan lokal memiliki beberapa sinonim, yakni kebijakan setempat, pengetahuan setempat, atau pengangan hidup setempat. Kearifan lokal atau kebijakan setempat "local wisdom" atau pengetahuan setempat "local kwowing" adalah pandangan hidup, ilmu pengetahuan, dan berbagai strategi kehidupan masyarakat lokal dalam menjalani kehidupan dengan berbagai permasalahannya (Koentjaraningrat, 2009). Menurut Rahyono (2009), kearifan lokal merupakan kecerdasan yang dimiliki oleh kelompok etnis tertentu sebagai kristalisasi dari pengalamannya. Istilah kearifan lokal digunakan untuk mengindikasikan adanya suatu konsep bahwa dalam kehidupan sosial-budaya lokal terdapat suatu keluhuran, ketinggian nilai-nilai, kebenaran, kebaikan, dan keindahan yang dihargai oleh warga masyarakat (Koentjaraningrat, 2009). Lebih lanjut dijelaskan bahwa nilai-nilai ini digunakan sebagai panduan atau pedoman untuk membangun pola hubungan dan memperjuangkan tujuan hidup. Wahab (2012: 18) mengatakan bahwa local genius (kearifan lokal) dapat menjadi sumber nilai bagi masyarakat pendukungnya. Kearifan lokal identik dengan ciri khas atau keunggulan yang dimiliki suatu kelompok masyarakat di suatu wilayah yang dapat dimanfaatkan untuk membangun peradaban manusia. Dengan demikian, dapat disimpulkan bahwa kearifan lokal merupakan nilai-nilai luhur yang terdapat dalam berbagai bidang kehidupan nyata seperti filosofi, pandangan hidup, kesehatan, arsitektur, dan sastra tradisional, digunakan sebagai pedoman untuk membangun pola hubungan dan memperjuangkan tujuan hidup. Nilainilai kearifan lokal perlu dilestarikan dan direvitalisasi agar tidak lapuk termakan zaman. Salah satunya melalui pengembangan bahan ajar berkearifan lokal.

\section{c. Literasi Bahasa Berbasis Kelas}

$$
\text { Berdasarkan dokumen }
$$

Gerakan Literasi Nasional (GLN), literasi didefinisikan sebagai: (a) suatu rangkaian kecakapan membaca, menulis, dan berbicara, kecakapan berhitung, dan kecakapan dalam mengakses dan menggunakan 
informasi; (b) sebagai praktik sosial yang penerapannya dipengaruhi oleh konteks; (c) sebagai proses pembelajaran dengan kegiatan membaca dan menulis sebagai medium untuk merenungkan, menyelidik, menanyakan, dan mengkritisi ilmu dan gagasan yang dipelajari; dan (d) sebagai pemanfaatan teks yang bervariasi menurut subjek, genre,dan tingkat kompleksitas bahasa. Menurut Word Economic Forum (2016), peserta didik memerlukan 16 keterampilan agar mampu bertahan di abad XXI, yakni literasi dasar (bagaimana peserta didik menerapkan keterampilan berliterasi untuk kehidupan sehari-hari), kompetensi (bagaimana peserta didik menyikapi tantangan yang kompleks), dan karakter (bagaimana peserta didik menyikapi perubahan lingkungan mereka). Dalam lingkup karakter, Penguatan Pendidikan Karakter (PPK) di Indonesia mengacu pada lima nilai utama, yakni (1) religius, (2) nasionalis, (3) mandiri, (4) gotong royong, (5) integritas (Depdikbud, 2018).

\begin{tabular}{lr}
\multicolumn{2}{c}{ Diperlukan pembangunan } \\
budaya literasi & yang \\
berkesinambungan & untuk \\
menterjadikan literasi rebagai
\end{tabular}
program yang akan menghasilkan generasi yang berkarakter. Menurut Beers dkk., (2009), pembangunan budaya literasi di sekolah hendaknya berfokus pada tigal hal, yaitu mengkondisikan lingkungan fisik yang kaya literasi. mengupayakan lingkuan sosial dan afektif sebagai modal komunikasi dan interaksi yang literal, dan mengupayakan sekolah sebagai lingkungan akademik yang literal. Terdapat sejulmah program yang dapat digunakan sebagai kegiatan untuk menterjadikan literasi bahasa berbasis kelas. Menurut Faizah, dkk. (2016) dan https://gurudigital.id/contoh-programgerakan-literasi, beberapa contoh program gerakan LBBK antara lain: (a) pemberdayaan mading setiap kelas; (b) merutinkan membaca buku nonpelajaran (buku cerita) sebelum proses pembelajaran; (c) posterisasi kelas atau dinding motivasi kelas; (d) membuat pohon literasi di setiap kelas; (e) membuat sudut baca di setiap kelas; (f) membuat papan karya literasi siswa di setiap kelas; dan (g) pemilihan duta literasi kelas.

Menurut panduan literasi di $\mathrm{SD}$, peta konsep strategi literasi dalam pembelajaran (di kelas), terdiri atas serangkaian kegiatan untuk memahami teks, yaitu: (a) menghubungkan teks dengan pengetahuan, pengalaman atau teks yang lain; (b) membuat inferensi atau prediksi tentang teks; (c) merumuskan pertanyaan; (d) memvisualisasikan pemahaman tentang teks; (e) mengidentifikasi ide penting/pokok dan pendukung; (f) mengkomunikasikan pemahaman terhadap teks (Depdikbud, 2018). Lebih dari itu, semua kegiatan ini dilakukan sebelum, selama, dan sesudah membaca sebuah teks.

$$
\text { Kurikulum } 2013 \text { telah }
$$

menekankan implementasi strategi literasi untuk meningkatkan kecakapan berpikir tingkat tinggi peserta didik di SD. Terdapat sejumlah indikator yang menunjukkan kegiatan LBBK telah terjadi, yakni: Indikator sebelum pembelajaran, saat pembelajaran, dan setelah pembelajaran (Depdikbud, 2018).

1) Sebelum Pembelajaran: (a) mengidentifikasi tujuan membaca/belajar; (b) membuat prediksi terhadap materi yang akan dipelajari, misalnya melalui fitur awal pada media pembelajaran (judul buku, judul film, dll); (c) mendiskusikan materi yang akan dipelajari melalui media yang menyenangkan (buku pengayaan, dongeng, film pendek, dll); dan (d) menghubungkan

materi 
pembelajaran dengan pengalaman siswa/subtema pembelajaran sebelumnya.

2) Selama Pembelajaran: (1). Untuk SD Kelas Rendah: (a) mengidentifikasi kosakata baru dan menebak maknanya melalui fitur teks (gambar atau konteks kalimat); (b) melafalkan kata-kata yang berulang dengan intonasi, pelafalan, dan irama yang benar; (c) menggambar peta konsep sederhana; (d) bermain peran/menyanyi/menceritakan kembali untuk mengekspresikan pemahaman terhadap materi pembelajaran; dan (e) Berdiskusi dengan teman dan bekerja dalam kelompok. (2) Untuk SD Kelas Tinggi: (a) mengidentifikasi kosakata baru dan menebak maknanya melalui fitur teks (gambar atau konteks kalimat); (b) membuat peta konsep/graphic organizer untuk mengungkapkan pemahaman terhadap teks; (c) membuat catatan/ringkasan selama membaca; dan (d) Think aloud selama membaca dan mendiskusikan pemahamannya dengan guru/teman.

3) Setelah Pembelajaran:

mengambil kesimpulan tentang materi pembelajaran dan mengaitkannya dengan kehidupan sehari-hari; (b) melakukan refleksi terhadap proses pembelajaran; dan (c) melakukan konfirmasi terhadap prediksi/pertanyaan yang dibuat pada kegiatan pendahuluan.

\section{d. Karakter Sosial}

Karakter sosial atau keterampilan sosial peserta didik merupakan keterampilan yang diperlukan dalam membangun sikap toleransi, seperti keterampilan menghargai perbedaan, menghargai pendapat orang lain, dan bersedia mendengarkan orang. Karakter/keterampilan sosial merupakan kecerdasan yang berkaitan dengan kemampuan seseorang untuk berinteraksi dengan orang lain, yang ditandai dengan kemampuan memperkirakan perasaan, temperamen, suasana hati, maksud dan keinginan dari pasangan interaksinya (Kurniati, 2016). Terdapat beberapa indikator karakter/keterampilan sosial peserta didik di Sekolah Dasar yang telah menunjukkan perkembangan dan selayaknya menjadi perhatian semua kalangan (Abbas, 2018; Beaty dalam Siska, 2011). Indikator-indikator dimaksud adalah: (1) memahami perasaan orang lain; (2) mengontrol kemarahan; (3) memperkenalkan diri; (4) menawarkan atau meminta; (5) mampu berkomunikasi; (6) memberi atau menerima pujian; (7) mendengarkan dengan tenang saat guru menerangkan pelajaran; (8) mengerjakan pekerjaan sekolah dengan baik; (9) melakukan apa yang diminta oleh guru. Lebih lanjut dijelaskan bahwa karakter/keterampilan sosial mempunyai ciri-ciri sebagai berikut (Rachmah, 2009; Siska, 2011).

a) Perilaku interpersonal. Perilaku interpersonal merupakan perilaku yang menyangkut keterampilan yang dipergunakan selama melakukan interaksi sosial (keterampilan menjalin persahabatan).

b) Perilaku yang berhubungan dengan diri sendiri. Perilaku ini merupakan keterampilan mengatur diri sendiri dalam situasi sosial, misalnya keterampilan menghadap stres, memahami perasaan orang lain, mengontrol kemarahan dan sejenisnya.

c) Perilaku yang berhubungan dengan kesuksesan akademis. Perilaku ini merupakan perilaku yang dapat mendukung prestasi belajar di sekolah, misalnya 
mendengarkan dengan tenang saat guru menjelaskan, mengerjakan pekerjaan sekolah dengan baik, dan semua perilaku taat aturan kelas.

d) Peer acceptance. Perilaku ini merupakan perilaku yang berhubungan dengan penerimaan sebaya, misalnya memberi salam, memberi dan meminta informasi, mengajak teman terlibat dalam suatu aktivitas dan dapat menangkap dengan tepat emosi orang lain.

e) Keterampilan Komunikasi. Keterampilan ini merupakan salah satu keterampilan yang diperlukan untuk menjalin hubungan sosial yang baik, misalnya menjadi pendengar yang responsif, mempertahankan perhatian dalam pembicaraan dan memberikan umpan balik terhadap kawan bicara.

\section{e. Keterampilan Berbahasa Produktif}

Keterampilan berbahasa terdiri atas empat jenis, yaitu menyimak, membaca, berbicara, dan menulis. Menurut Morley (dalam Musaddat, 2015), dalam kehidupan sehari-hari, intensitas penggunaan keterampilan menyimak mencapai $50 \%$, berbicara $25 \%$, membaca $15 \%$, dan menulis 10\%. Menurut Tarigan (2011), keempat keterampilan berbahasa ini dapat dikelomokkan menjadi dua bagian, yaitu keterampilan berbahasa reseptif dan produktif. Keterampilan berbahasa reseptif adalah jenis keterampilan berbahasa yang bersifat menyerap informasi atau pesan. Keterampilan menyimak dan membaca termasuk dalam jenis keterampilan berbahasa reseptif. Sementara itu, keterampilan berbahasa produktif adalah keterampilan yang bersifat menghasilkan informasi atau pesan. Yang termasuk kelompok keterampilan ini adalah berbicara dan menulis.
Berbicara merupakan alat untuk mengomunikasikan gagasan yang disusun dan dikembangkan sesuai dengan kebutuhan pendengar (Tarigan, 2011:15). Taryono (1999:10) menjelaskan bahwa berbicara juga berarti proses pemindahan atau penyeberangan gagasan dari benak pembicara ke benak pendengar dengan menggunakan simbol-simbol fonetis sebagai media pemahamannya dan terjadi melalui serangkaian proses yang rumit. Pendapat lain dikemukakan oleh Brigance (dalam Taryono, 1999) yang menyatakan bahwa berbicara merupakan aktivitas mental dan psikis yang bersifat produktif dan lisan. Dalam konteks ini, berbicara merupakan kegiatan berbahasa yang aktif produktif dari seorang pemakai bahasa, yang menuntut prakarsa nyata dalam penggunaan bahasa untuk mengungkapkan diri secara lisan.

Menurut Taryono (1999:5459) terdapat dua faktor yang menunjang keefektifan berbicara, yaitu faktor kebahasaan dan nonkebahasaan. Faktor kebahasaan meliputi empat hal, yaitu: ketepatan ucapan; tekanan nada, sandi, dan durasi; pilihan kata atau diksi; dan ketepatan struktur kalimat. Sementra itu, faktor nonkebahasaan meliputi delapan hal, yaitu: sikap pembicara, pandangan mata, keterbukaan, gerakgerik dan mimik yang tepat, kenyaringan suara, kelancaran, penguasaan topik, dan penalaran (Taryono, 1999:59-67). Di samping faktor penunjang tersebut, juga terdapat faktor penghambat dalam berbicara. Di dalam kegiatan berbicara terdapat dua penghambat, yaitu hambatan internal dan eksternal. Hambatan internal adalah hambatan yang berasal dari dalam diri pembicara, sedangkan hambatan eksternal adalah hambatan yang berasal dari luar pembicara (Taryono, 
1999:68). Adapun hambatan internal yang dimaksud terdiri atas tiga bagian, yaitu: hambatan yang bersifat fisik, hambatan yang bersifat mental atau psikis, dan hambatan lain-lain berupa kurangnya penguasaan kaidah tata bahasa, kurangnya pengalaman berbicara, kurangnya perhatian terhadap berbicara. Sedangkan hambatan eksternal menurut Taryono (1999:72-77) meliputi: (1) hambatan yang berupa suara, (2) hambatan yang berupa gerak, (3) hambatan yang berupa cahaya, dan (4) hambatan yang berupa jarak.

Selain berbicara, yang juga termasuk keterampilan berbahasa produktif adalah keterampilan menulis. Byrne dalam Musaddat (2015) menjelaskan bahwa keterampilan menulis merupakan kemampuan menuangkan buah pikiran ke dalam bahasa tulis melalui kalimatkalimat yang dirangkai secara utuh, lengkap, dan jelas sehingga buah pikiran tersebut dapat dikomunikasikan kepada pembaca dengan berhasil. Menurut Tarigan (2018:3), menulis adalah salah satu keterampilan berbahasa yang produktif dan ekspresif, yang digunakan untuk berkomunikasi secara tidak langsung dengan media bahasa tulis. Menurut Nurgiantoro (2011: 273), menulis adalah aktivitas mengungkapkan gagasan melalui media bahasa. Lebih lanjut dijelaskan bahwa menulis merupakan kegiatan produktif dan ekspresif sehingga penulis harus memiliki kemampuan dalam menggunakan kosakata, tata tulis, dan struktur bahasa. Dalam kontek ini, menulis berarti aktivitas pengekpresian ide, gagasan, pikiran atau perasaan ke dalam lambanglambang kebahasaan. Konsep yang sederhana tentang menulis dikemukakn oleh Superno dan Yunus (2017), yang menyatakan bahwa menulis merupakan kegiatan menyampaikan pesan (komunikasi) dengan mengunakan bahasa tulis sebagai media atau alatnya. Dengan demikian, menulis merupakan serangkaian kegiatan untuk mengemukakan suatu ide atau gagasan dalam bentuk lambang bahasa tulis agar dapat ditangkap informasi atau idenya oleh orang lain.

Sebagai suatu proses, menulis merupakan serangkaian aktivitas (kegiatan) yang terjadi dan melibatkan beberapa fase (tahap) yaitu fase pramenulis (persiapan), penulisan (pengembangan isi karangan), dan pascapenulisan (telaah dan revisi atau penyempurnaan tulisan) yang memerlukan banyak latihan. Sejalan dengan itu, Suparno dan Yunus (2017) mengungkapkan bahwa menulis, di samping sebagai proses, juga merupakan suatu kegiatan yang kompleks karena melibatkan cara berpikir yang teratur dan berbagai persyaratan yang berkaitan dengan teknik penulisan, antara lain: (1) adanya kesatuan gagasan; penggunaan kalimat yang jelas; (3) paragraf disusun dengan baik; (4) penerapan kaidah ejaan yang benar; dan (5) penguasaan kosakata yang memadai. Oleh karena itu, dalam kegiatan menulis diperlukan adanya kompleksitas kegiatan untuk menyusun karangan secara baik yang meliputi: (1) keterampilan gramatikal, (2) penuangan isi, (3) keterampilan stilistika, (4) keterampilan mekanis, dan (5) keterampilan memutuskan (Heaton dalam Suparno dan Yunus, 2017).

Dalam patokan sederhana, tahapan proses menulis dibagi menjadi empat langkah: (1) pratulis, (prewriting), (2) menulis, (3) merevisi, (4) uji-baca (proofreading) naskah atau publikasi. Hal ini hampir senada dengan pendapat Tompkins (dalam Musaddat, 2015) menyajikan lima tahap dalam menulis, yaitu: 1) pramenulis; 2) pembuatan draft; 3) merevisi; 4) menyunting; dan 5) 
berbagi (sharing). Lebih lanjut dijelaskan bahwa tahap-tahap menulis ini bukanlah kegiatan yang linear (urut dari awal hingga akhir), tetapi merupakan proses berdaur ulang.

\section{Alternatif Metode Pengembangan}

\section{Alternatatif}

metode pengembangan yang dapat dilakukan dalam rangka mengembangkan bahan ajar digital berbasis kearifan lokal adalah melalui penelitian pengembangan (Research and Development) atau R\&D. Penelitian dan Pengembangan (R\&D) adalah istilah yang biasa digunakan untuk menggambarkan kegiatan yang dilakukan oleh perusahaan dan entitas lain seperti pengusaha perorangan untuk menciptakan peningkatan produk dan proses (Hull, 2006; Sanjaya, 2016). Penelitian dan pengembangan tidak hanya membahas desain dan pengembangan produk, tetapi juga evaluasi. Dalam konteks ini, penelitian dan pengembangan menghasilkan produk yang nantinya dapat diuji keefektivitasnya. Untuk pengembangan bahan ajar digital berbasis kearifan lokal ini dapat menggunakan R\&D versi Borg dan Gall. Tahap pengembangan Borg \& Gall terdiri atas: (1) penelitian/studi pendahuluan dan pengumpulan data (research and information collecting), (2) perencanaan (planning), (3) pengembangan draf produk (develop preliminary form of product), (4) uji coba lapangan awal (preliminary field testing) atau dalam penelitian ini merupakan uji validasi oleh ahli, (5) merevisi hasil uji coba lapangan awal (main product revision), (6) uji coba lapangan utama atau dalam penelitian ini adalah uji coba skala kecil (main field testing), (7) merevisi produk hasil uji lapangan utama (operational product revision), (8) uji pelaksanaan lapangan atau dalam penelitian ini adalah uji coba lapangan/kelas (operational field testing), (9) revisi produk akhir (final product revision), dan (10) diseminasi dan implementasi (dissemination and implementation).
Untuk uji pengaruh, dari hasil penelitian ini, sebaiknya ditetapkan populasi dan sampel penelitiannya. Misalnya, populasinya adalah semua siswa kelas IV atau V SD yang ada di Kota Mataram. Di Kota Mataram terdapat 120 SD. SD dimaksud tersebar pada lima kecamatan. Sampel penelitian ini akan dipilih 10 SD. Teknik pengambilan sampel akan menggunakan teknik kluster random sampling, yakni melalui pengelompokkan kualitas sekolah dan kluster daerah. Dalam hal ini, akan dipilih sekolah dengan tipe maju/rujukan dan biasa/nonrujukan (istilah diknas setempat) dan masing-masing dua sekolah dari setiap kecamatan yang ada. Selanjunta, kedua sekolah dimaksud akan dipilih secara acak melalui undian.

Jika demikian halnya, data akan dikumpulkan melalui observasi, wawancara, dan angket. Data dapat dianalisis menggunakan program berbantuan komputer SPSS 20 for windows. Sebelum dilakukan analisis data, dilakukan uji prasyarat terlebih dahulu yaitu uji normalitas, uji homogenitas, dan uji linearitas regresi. Sementara itu, uji pengaruh menggunakan uji-T (independent test sample) untuk mengetahui keputusan hipotesis penelitian. Adapun gambaran rancangan penelitian dan pengembangan ini lebih rinci dapat dicermati pada bagan 1 berikut.

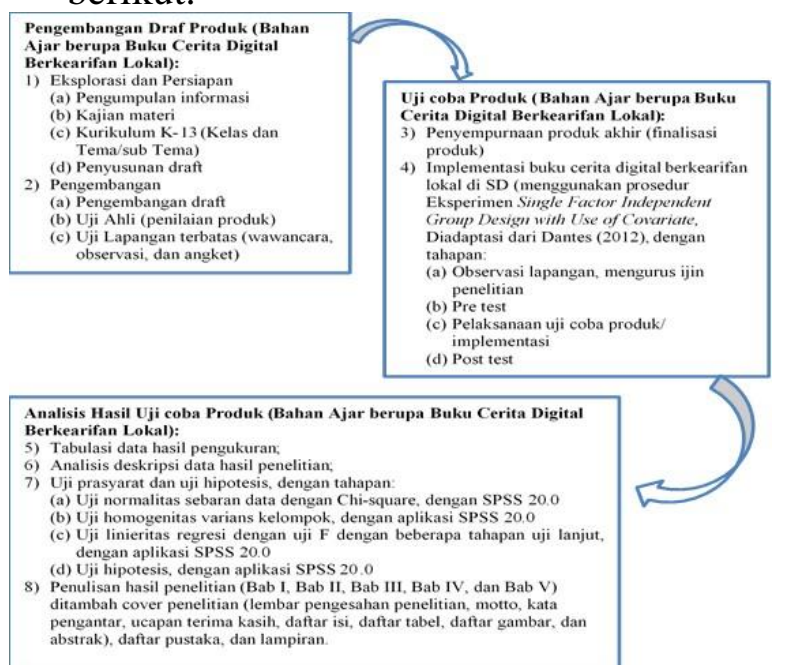

Bagan 1. Tahapan Penelitian dan Pengembangan Bahan Ajar Digital Berbasis Kearifan Lokal 
Berdasarkan landasan pemikiran di atas, masalah utama yang dapat dikaji dan diteliti melalui penelitian dan pengembangan ini adalah terkait model bahan ajar digital berkearifan lokal yang dapat digunakan sebagai bahan literasi bahasa berbasis kelas serta pengaruhnya terhadap karakter sosial dan keterampilan berbahasa siswa Sekolah Dasar? Secara rinci masalah penelitian dan pengembangan ini nantinya terkait dengan: (1) rancangan atau model (prototife) bahan ajar digital berkearifan lokal; implementasi dari rancangan atau model bahan ajar digital berkearifan lokal pada program literasi bahasa berbasis kelas atau pada pembelajaran di kelas; (3) hasil uji coba rancangan atau model bahan ajar digital berkearifan lokal terhadap karakter sosial siswa kelas tinggi Sekolah Dasar; dan (4) hasil uji coba rancangan atau model bahan ajar digital berkearifan lokal terhadap keterampilan berbahasa siswa kelas tinggi Sekolah Dasar. Dalam hal ini, dapat dikemukakan keterbatasan penelitian yang nantinya akan dilakukan meliputi: (1) fokus pada bahan ajar digital tentang cerita-cerita lokal Sasak, yang kaya dengan nilai-nilai karakter; (2) karakter sosial berupa kecerdasan interpersonal; (3) keterampilan berbahasa berupa keterampilan berbahasa produktif karena lebih dekat dengan karakter sosial; dan (4) siswa SD khususnya siswa kelas tinggi.

\section{SIMPULAN}

Berdasarkan hasil dan pembahasan dapat disimpulkan bahwa kajian berupa penelitain dan pengembangan bahan ajar digital berbasis kearifan lokal serta pengaruhnya terhadap arakter sosial dan keterampilan berbahasa produktif siswa kelas V SD perlu dilakukan karena dua pertimbangan utama. Kedua pertimbangan dimaksud adalah (1) terdapat sejumlah fakta yang mendasari bahwa kajian ini layak dijadikan sebagai masalah penelitian, antara lain: (a) keharusan peserta didik untuk memeiliki kompetensi global berupa empati dan kemampuan berkomunikasi; (b) sistem pendidikan Indonesia masih belum berhasil melahirkan generasi berkarakter, cerdas, dan terampil; (c) keharusan untuk menggunakan teknologi dalam pendidikan; (d) belum efektifnya program literasi berbasis kelas di SD; dan (e) banyaknya hasil penelitian pengembangan berbasis teknologi yang telah berhasil meningkatkan kualitas pembelajaran; dan (2) terdapat sejumlah hasil kajian teori yang akan memperkuat penelitian ini, yakni teori tentang: (a) bahan ajar digital; (b) kearifan lokal; (c) literasi bahasa berbasis kelas; (d) karakter sosial; dan (e) keterampilan berbahasa. Di samping itu, juga diusulkan model penelitian dan pengembangan yang dapat digunakan, yaitu model penelitian dan pengembangan (R\&D) versi Borg dan Gall, yang terdiri atas 10 langkah pengembangan.

\section{SARAN}

Terkait hasil kajian literatur ini, disarankan beberapa hal, yakni (1) perlu segera dilakukan kajian selanjutnya terkait bentuk-bentuk kearifan lokal yang dapat diintegrasikan dalam bahan ajar (buku cerita) SD; (2) perlu segera dilakukan kajian lanjutan terkait indikator dari grand teori yang dibutuhkan untuk pengembangan dimaksud; dan (3) perlu dimatangkan pilihan metode pengembangan yang akan digunakan sesuai dengan kebutuhan dan hasil kajian dasar yang dilakukan.

\section{UCAPAN TERIMAKASIH}

Ucapan terimakasih terutama disampaikan kepada I Gede Rasben Dantes yang telah memotivasi penulis untuk melakukan kajian ini. Ucapan yang sama juga disampaikan kepada kaprodi S-3 Pendas Universitas Pendidikan Ganesha, Prof. Suari, Prof. Dantes, Prof. Putrayasa, dan temanteman seperjuangan yang telah mendukung penyelesaian kajian ini.

\section{DAFTAR PUSTAKA}

Abbas, Ersis Warmansyah. (2018). Penguatan Pendidikan IPS di Tengah Isu-isu Global (Prosiding Seminar Nasional). Banjar Masin: Prodi PIPS FKIP Univ. Lambung Mangkurat Banjarmasin. 
Arikunto, S. (2013). Metode Penelitian Kuantitatif Kualitatif dan $R \& D$. Alfabeta: Bandung.

Beers, C. S., Beers J. W., \& Smith J. O. (2009). A Principal's Guide to Literacy Instruction. New York: Guilford Press

Brown, Susan. (2018). Best Practices in $21^{\text {st }}$ Century Learning Environments: A Study of Two P21 Exemplar Schools. Brandman University, Irvine, California School of Education.https://digitalcommons.br andman.edu/cgi/viewcontent.cgi?arti cle $=1197 \&$ context $=$ edd_dissertations

Chan, Faizal, Hendra Budiono, dan Panut Setiono. (2019). Pengembangan Multimedia Interaktif Berbasis Keterampilan Proses Dasar pada Materi Tumbuhan dan Bagianbagiannya di Sekolah Dasar. ELSE (Elementary School Education Journal). Vol. 3 No. 1 Februari 2019: 9 - 17;

Depdikbud. (2018). Strategi Literasi dalam Pembelajaran di Sekolah Dasar (Modul Materi Penyegaran Instruktur Kurikulum 2013). Jakarta: Direktorat Pembinaan Sekolah Dasar, Dirjen Dikdasmen, Kementerian Pendidikan dan Kebudayaan

Dick, Walter dan Carey, Lou (2005). The Systematic Design of Instruction. Palo Alto, California, Scott: Foreman and Company

Doğan, Yadigar dan Gönül Onur Sezer. (2010). A Study on Learning Environments of Elementary School Students Taking Social Studies Course: Bursa Sample. "World Conference on Educational Sciences" (Istanbul, Turkey, February 4-8, 2010). co-organized by the Bahcesehir University. Turkey: Devid Publishing

Faizah, D.U., dkk. (2016). Panduan Gerakan Literasi Sekolah di Sekolah Dasar. Jakarta: Direktorat Pembinaan Sekolah Dasar, Dirjen Dikdasmen, Kemendikbud
Borg, W.R \& Gall, M.D. (1996). Edacational Research: An Introduction. New York: Longman.

Fadhilah, Nur and Dhea Adela. (2018). "Motivation in Social Science Learning in Digital Era: Case Study Of Multimedia Use." SHEs: Conference Series 1 (1) (2018) 575583.

Gall, Meredith D.Gall Joyce P. \& Borg, Walter R. (2003). Educational Research An Introduction, Seventh Edition. Boston: Pearson Education Inc

International Literacy Association. (2016). Frameworks for literacy education reform [White paper]. Newark, DE: Author.

Ismail, Taufik. (2003). Agar Anak Bangsa Tak Rabun Membaca tak Pincang Mengarang.

(Pidato

Penganugerahan Gelar Kehormatan Doctor Honoris Causa di Bidang Pendidikan Sastra). Yogyakarta: Universitas Negeri Yogyakarta.

Komalasari, Kokom. (2010). Pembelajaran Kontektual Konsep dan Aplikasi. Bandung: Refika Aditama

Keraf, G. (2018). Komposisi: Sebuah Pengantar Kemahiran Bahasa. Ende Flores: Nusa Indah

Koentjaraningrat. (2009). Pengantar Ilmu Antropologi. Jakarta: Wedatama Widyasastra.

Kurniati, E. (2016). Permainan Tradisional dan Perannya dalam Mengembangkan Keterampilan Sosial Anak. Bandung: Kencana.

Mabruri, Haeru; Farid Ahmadi, dan Tri Suminar. (2019). The Development of Science Mobile Learning Media to Improve Primary Students Learning Achievements. Journal of Primary Education. Vol. 8 (1), 2019: $108-116$

Madona, A. Sri. (2017). "Design of Interactive Multimedia Based IPS Learning Module Using CTL Approach Based on Student Tendency Response in the Use of 
Learning Module in Grade IV." ICES 2017: 627 - 632.

Mahsun. (2017). Metode Penelitian Bahasa. Jakarta: PT Raja Grafindo Persada

Mahyudi, J., \& Musaddat, S. (2008). Kearifan lokal yang tercermin pada istilahistilah adat masyarakat Sasak di Lombok: laporan penelitian dosen muda. Laporan Penelitian tidak dipublikasikan, LPPM Universitas Mataram.

Marhaeni, Anak Agung Istri Ngurah, I Komang Wahyu Wiguna, I Made Gunamantha, and Nyoman Dantes. (2018) Content and Context: A Children's Book to Support Learning in the 2013 Curriculum. Advances in Social Science, Education and Humanities Research, volume 178. 1st International Conference of Innovation in Education (ICoIE 2018)

Kurniati, E. (2016). Permainan Tradisional dan Perannya dalam Mengembangkan Keterampilan Sosial Anak. Bandung: Kencana.

Siska, Y. (2011). Penerapan metode bermain peran (role playing) dalam meningkatkan keterampilan sosial dan keterampilan berbicara anak usia dini. J. Educ, 1(1).

Rachmah, H. (2009). Kontribusi Kompetensi Guru, Proses dan Hasil Belajar terhadap Keterampilan Berpikir Kritis dan Keterampilan Sosial. Disertasi. Bandung: Sekolah Pascasarjana Universitas Pendidikan Indonesia.

Musaddat, S. (2015). Peningkatan Keterampilan Berbahasa Indonesia. Mataram: Argapuji Press.

Musaddat, S. dan AAIN Marhaeni (2020). Keterlaksanaan Gerakan Literasi Bahasa Berbasis Kelas pada Jenjang Sekolah Dasar di Pulau Lombok: Peluang Pemanfaatan Teknologi Digital Sebagai Upaya Optimalisasi. Mabasan 2 (Vol. 14 (2)), 143-160.

Nur, T., Sabara, H. Z., \& Wekke, I. S. (2018). Teknik Menulis Karya Ilmiah: Dengan 8 Senjata Aplikasi
Pendukung Produktivitas Riset.

Deepublish.

Nurhayati, E.S. (2016). "Pengembangan

Multimedia Interaktif Materi IPS

Berbasis Inquiri Kelas V Tema

Sejarah Peradaban Indonesia" Tesis, tidak dipublikasikan. PPS

Universitas Negeri Malang

Nurgiantoro, B. (2011). Penilaian dalam

Pengajaran Bahasa dan Sastra.

Yogyakarta: BPFE

Rachmah, H. (2009). Kontribusi Kompetensi Guru, Proses dan Hasil Belajar terhadap Keterampilan Berpikir Kritis dan Keterampilan Sosial. Disertasi. Bandung: Sekolah Pascasarjana Universitas Pendidikan Indonesia.

Rahyono, F.X. (2009). Kearifan Budaya dalam Kata. Jakarta : Aksara Baru.

Reimers, Fernando. (2019). "'Global Competency' Is Imperative for Global Success." The Chronicle of Higher Education, 30 Jan. 2009. General OneFile, http://link.galegroup.com/apps/doc/A 192644104/GPS?u=ptn054\&sid=GP S\&xid=4163d96f. Accessed 21 Jan. 2019.

Result Prom PISA. (2015). Programe For International Student Assessment. https://www.bps.go.id/linkTableDina mis/view/id/1054. Diakses tanggal 21 Januari 2019

Richey, R. C., \& Klein, J. D. (2014). Design and development research. In Handbook of research on educational communications and technology (pp. 141-150). Springer, New York, NY.

Sanjaya, D. H. W. (2016). Penelitian Tindakan Kelas. Prenada Media.

Siska, Y. (2011). Penerapan metode bermain peran (role playing) dalam meningkatkan keterampilan sosial dan keterampilan berbicara anak usia dini. J. Educ, l(1).

Setiawan, Debi Adis, Wahjoedi, Siti Malikhah Towaf. (2018). Multimedia Interaktif Buku Digital 3D pada Materi IPS Kelas IV 
Sekolah Dasar. Jurnal Pendidikan:

Teori, Penelitian, dan

Pengembangan, Vol. 3 No. 9, 2018:

1133 - 1141;

Sugiyono. (2011). Metode Penelitian

Kuantitatif, Kualitatif, dan $R \& D$.

Bandung: Alfabet

Suparno dan Muh. Yunus. (2017).

Keterampilan Dasar Menulis.

Jakarta: UT

Tarigan, H.G. (2018). Menulis Sebagai Suatu

Keterampilan Berbahasa. Bandung: Angkasa.

Tarigan, H.G. (2011). Berbicara Sebagai Suatu Keterampilan Berbahasa. Bandung: Angkasa.

Taryono. (1999). Berbicara dan Komponenkomponennya. Bandung: Angkasa

Thiagarajan, S., Semmel, D. S \& Semmel, M. I. (1974). Instructional Development for Training Teachers of Expectional Children. Minneapolis, Minnesota: Leadership Training Institute/Special Education, University of Minnesota.

Tim PLPG Unram. (2018). "Panduan Workshop Pengembangan Perangkat Pembelajaran". Mataram: Universitas Mataram

Wadi, Khairil. (2013). IPS SD Kelas Tinggi. Mataram: Program PPKHB Universitas Mataram

Wardani, I.G.A.K., dkk. (2017). Teknik Menulis Karya Ilmiah. Jakarta: Universitas Terbuka

Wijayanti, Widya dan Stefanus Christian Relmasira. (2019). Pengembangan Media Power Point IPA untuk Siswa Kelas IV SD Negeri Samirono. Jurnal Penelitian dan Pengembangan Pendidikan. Vol. 3 (2) pp. 77-83 